\title{
ASSOCIATIONS BETWEEN PARITY, NUTRITION STATUS, LEVEL OF STRESS, AND DELAYED MENOPAUSE IN TANGERANG, WEST JAVA
}

\author{
Henalusti ${ }^{1)}$, Ninik Wahyuni²), Aquartuti Tri D ${ }^{3)}$ \\ 1)District Health Office, Tangerang, Banten \\ ${ }^{2}$ School of Health Polytechnics, Banten \\ 3)Masters Program in Public Health, Sebelas Maret University
}

\begin{abstract}
Background: Decreasing number of ovarian follicles triggers the occurrence of menopause. Menopause is a natural phenomenon in reproductive health. However, delayed menopause can increase the number of cancer-triggering hormones. Deceleration of menopause can be affected by an increase in the number of pregnancy and birth that stimulate the prose-up regulating for anti-Mullerian hormone (AMH). The hormone may indicate an increase in the number of follicles. Nutritional status and decreased cortisol level in a person experiencing stress are also suspected to affect the deceleration of menopause. This study aimed to determine the associations between parity, nutrition status, level of stress, and delayed menopause in Tangerang, West Java.

Subjects and Method: This was an analytic observational study using case control design. This study was carried out at Elderly Clinic, Sukamulya subdistrict, Tangerang, West Java. A sample of 150 women were selected for this study consisting 101 women experiencing late menopause (case) and 41 women experiencing normal menopause (control) using purposive sampling. The dependent variable was age of menopause. The independent variables were parity, nutritional status, and psychological stress. The data on parity were obtained from medical record. Stress level was measured by questionnaire, including data on physical, task, role, and interpersonal demands. Nutritional status was measured by body mass index (BMI). The data were analyzed by multiple logistic regression.

Results: Delayed menopause was associated with increased parity $(\mathrm{OR}=$ $3.49 ; 95 \% \mathrm{CI}=1.56$ to $7.81 ; \mathrm{p}=0.002)$, higher $\mathrm{BMI}(\mathrm{OR}=1.79 ; 95 \% \mathrm{CI}=0.79$ to 4.06; $\mathrm{p}=0.160)$, and lower stress $(\mathrm{OR}=0.15 ; 95 \% \mathrm{CI}=0.06$ to $0.34 ; \mathrm{p}<0.001)$. Conclusion: Delayed menopause is associated with increased parity, higher $\mathrm{BMI}$, and lower stress.
\end{abstract}

Keywords: delayed menopause, parity, BMI, stress

Correspondence: Ninik Wahyuni. Program in Midwifery. School of Health Polytechnics, Rangkasbitung, Banten. Email: ninikasih@gmail.com. Mobile: $+6281310626579$ 